\title{
Inhibition of the Oxidation of Corn Oil Stripped of Tocopherols and Refined Olive Oil by Thiols
}

\author{
Ioannis G. Roussis*,1, Despina Papadopoulou ${ }^{1}$ and Maria Sakarellos-Daitsiotis ${ }^{2}$ \\ ${ }^{1}$ Laboratory of Food Chemistry; ${ }^{2}$ Laboratory of Biochemistry, Department of Chemistry, University of Ioannina, 45110 \\ Ioannina, Greece
}

\begin{abstract}
The ability of $\mathrm{N}$-acetyl-cysteine and glutathione to inhibit the oxidation of corn oil stripped of tocopherols and refined olive oil was examined.

The oxidative stability of corn oil stripped of tocopherols at $50{ }^{\circ} \mathrm{C}, 120{ }^{\circ} \mathrm{C}$ and $180{ }^{\circ} \mathrm{C}$ was evaluated. The absorbances at $234 \mathrm{~nm}$ and $270 \mathrm{~nm}$, and $p$-anisidine value were monitored. $N$-acetyl-cysteine and glutathione inhibited the oxidation of oil, $N$-acetyl-cysteine at a higher degree. In comparison to BHA at $200 \mathrm{mg} / \mathrm{L}$, both thiols at $20-40 \mathrm{mg} / \mathrm{L}$ exhibited lower $\left(50{ }^{\circ} \mathrm{C}\right.$ and $\left.120^{\circ} \mathrm{C}\right)$ or similar $\left(180^{\circ} \mathrm{C}\right)$ antioxidant activities. Compounds similar to the two thiols but not containing $-\mathrm{SH}$ group, $\mathrm{N}$-acetyl-serine and oxidized glutathione, exhibited very low or no antioxidant activities. The oxidative stability of refined olive oil at $20{ }^{\circ} \mathrm{C}$ was determined by monitoring the peroxide value. $\mathrm{N}$-acetyl-cysteine and glutathione at $20 \mathrm{mg} / \mathrm{L}$ exhibited antioxidant activities comparable to that of BHA at $200 \mathrm{mg} / \mathrm{L}$.

Present results show the ability of $\mathrm{N}$-acetyl-cysteine and glutathione to inhibit the oxidation of corn oil stripped of tocopherols and refined olive oil indicating that thiols can inhibit the oxidation of any oil.
\end{abstract}

Keywords: $N$-acetyl-cysteine, glutathione, thiols, oxidation, oil.

\section{INTRODUCTION}

SH-containing amino acids and peptides are natural components in our diet and play significant physiological roles in vivo as nucleophiles and scavengers of free radicals [1]. Many foods contain glutathione at various levels, since it is present in most plant and animal tissues [2,3]. $\mathrm{N}$-acetylcysteine is an excellent nutritional source of cysteine for humans [1]. It has been proposed for use in foods for particular nutritional uses and for special medical purposes [4].

Lipid oxidation is a major cause of spoilage in foods and its products are potentially toxic. Antioxidants are widely used in many foods to prevent fat rancidity. Synthetic antioxidants such as butylated hydroxyanisole (BHA) are widely used because they are effective and cheaper than natural ones. However, the safety and toxicity of synthetic antioxidants have raised important concerns. Hence, considerable interest has been expressed for the use of natural antioxidants because of their potential nutritional and therapeutic properties [5]. The antioxidant activities of SH-containing amino acids and peptides against the peroxidation of lipids have been reported [6-9].

The main effort of present study was to evaluate the ability of $\mathrm{N}$-acetyl-cysteine, and glutathione to inhibit the oxidation of corn oil stripped of tocopherols and refined olive oil.

\section{MATERIALS AND METHODS}

\section{Reagents and Oils}

$\mathrm{N}$-acetyl-cysteine, $\mathrm{N}$-acetyl-serine, glutathione, oxidized glutathione and butylated hydroxyanisole (BHA) were pur-

\footnotetext{
*Address correspondence to this author at the Laboratory of Food Chemistry; University of Ioannina, 45110 Ioannina, Greece; Tel: ++30 26510 98344; Fax: ++30 26510 98782; E-mail: iroussis@uoi.gr
}

chased from Sigma (St. Louis, MO, USA). Corn oil stripped of tocopherols was purchased from INC Biochemicals, Inc. (Aurora, OH, USA). Olive oil used was a refined one (Elais, Athens, Greece).

\section{Oxidation of Corn Oil Stripped of Tocopherols}

The ability of amino acids/peptides to inhibit the oxidation of corn oil stripped of tocopherols was evaluated at 50, 120 and $180^{\circ} \mathrm{C}$. Each amino acid/peptide or BHA was added in solid form and dissolved using ultrasonic bath for $10 \mathrm{~min}$. A standard amount of corn oil stripped of tocopherols was put into glass bottles of $5 \mathrm{~mL}$ capacity $(\mathrm{D}=2.3 \mathrm{~cm}, \mathrm{~h}=2.4$ $\mathrm{cm})$. Two milliliters were used for experiments at $50{ }^{\circ} \mathrm{C}$, while $1 \mathrm{~mL}$ for those at 120 or $180^{\circ} \mathrm{C}$. Bottles were put open in an oven at the appropriate temperature. Bottles were taken at periodic intervals and the oxidative stability of oil was evaluated by measuring the absorbances at $234 \mathrm{~nm}$ and 270 $\mathrm{nm}$, and by determining the $p$-anisidine value.

For the UV absorbances, $10 \mu \mathrm{L}$ of each sample were mixed with $10 \mathrm{~mL}$ of isooctane and the absorbances were followed at $234 \mathrm{~nm}$ and $270 \mathrm{~nm}$ using cells of $1 \mathrm{~cm}$. Isooctane was used as a blank. When it was necessary, the mixtures were diluted more with isooctane in order to take a measurable absorbance, which was then corrected according to this extra dilution [10]. For $p$-anisidine value, $0.1-0.2 \mathrm{~g}$ of each sample to the nearest $0.001 \mathrm{~g}$ were put into a $5 \mathrm{~mL}$ volume flask and diluted to volume with iso-octane. The absorbance at $350 \mathrm{~nm}(\mathrm{Ab})$ was measured using cells of $1 \mathrm{~cm}$ and the solvent as a blank. Five milliliters of each oil solution or solvent were mixed with $1 \mathrm{~mL} p$-anisidine reagent $(2.5 \mathrm{~g} / \mathrm{L}$ in acetic acid). After exactly 10 minutes the absorbance at $350 \mathrm{~nm}$ (As) of each sample mixture was measured using the solvent mixture as blank. The $p$-anisidine value ( $p$-AV) was calculated by the formula $p-\mathrm{AV}=5 \mathrm{x}(1.2 \mathrm{As}-\mathrm{Ab}): \mathrm{m}$, where As 
is the absorbance of oil solution after reaction with $p$-anisidine reagent, $\mathrm{Ab}$ is the absorbance of the solution of the oil, $\mathrm{m}$ is the mass, in gr, of the test portion [10]. In all cases, the absorbance was measured using a Jenway 6505 UV/Vis spectrophotometer (Jenway, Dunmow, England).

\section{Oxidation of Refined Olive Oil}

The ability of $N$-acetyl-cysteine and glutathione to inhibit the oxidation of refined olive oil was evaluated at $20{ }^{\circ} \mathrm{C}$. Each thiol or BHA was added in solid form and dissolved using ultrasonic bath for $10 \mathrm{~min}$. Thirty $\mathrm{mL}$ of refined olive oil were put in glass bottles of $30 \mathrm{~mL}$ capacity $(\mathrm{D}=2.5 \mathrm{~cm}$, $\mathrm{h}=6 \mathrm{~cm})$. Bottles were stored open at $20{ }^{\circ} \mathrm{C}$. Bottles were taken at periodic intervals and the oxidative stability of olive oil was evaluated by determining the peroxide value (PV).

For peroxide value determination, a known weight of sample (about $2 \mathrm{~g}$ ) was weighed into a flask with cup, and air oxygen was removed using nitrogen gas. The sample was dissolved in $10 \mathrm{~mL}$ chloroform; $15 \mathrm{~mL}$ acetic acid and $1 \mathrm{~mL}$ saturated solution of potassium iodine (KI) were added, and mixed for $1 \mathrm{~min}$. The mixture was left in the dark at room temperature for $5 \mathrm{~min}$. Then, distilled water $(75 \mathrm{~mL})$ was added and the mixture shaken vigorously. Freshly prepared starch solution $(1 \%, 1 \mathrm{~mL})$ was added and the resulting solution titrated with $0.002 \mathrm{~N}$ solution sodium thiosulphate $\left(\mathrm{Na}_{2} \mathrm{~S}_{2} \mathrm{O}_{3}\right)$ until the colour became clear. A blank containing no sample was also prepared. The peroxide value was calculated using the formula $\mathrm{PV}=[1000 \mathrm{x}(\mathrm{Vs}-\mathrm{Vb}) \mathrm{xN}] / \mathrm{W}$, where
$\mathrm{Vs}$ and $\mathrm{Vb}$ is the volume of $\mathrm{Na}_{2} \mathrm{~S}_{2} \mathrm{O}_{3}$ used for titration of sample and blank respectively, $\mathrm{N}$ is the normality of $\mathrm{Na}_{2} \mathrm{~S}_{2} \mathrm{O}_{3}$ and $\mathrm{W}$ is the amount of sample $(\mathrm{g})$. PV is expressed as milliequivalents (meq) of active oxygen per $\mathrm{kg}$ of sample [7, 10].

\section{Statistical Analysis}

Each experiment was repeated three times, and results reported here are the means of the three runs. The one way analysis of variance (ANOVA), using the Duncan test at a level of significance $p<0.05$ was used for the statistical analysis (SPSS 11.5).

\section{RESULTS AND DISCUSSION}

The antioxidant activities of $\mathrm{N}$-acetyl-cysteine, $\mathrm{N}$-acetylserine, glutathione and oxidized glutathione were evaluated in tocopherol free corn oil at 50, 120 and $180^{\circ} \mathrm{C}$. Moreover, BHA was used for comparison. Both primary and secondary oxidation products were followed. Conjugated dienes (A234 $\mathrm{nm})$, conjugated trienes (A270 $\mathrm{nm})$, and high-molecularweight carbonyl compounds ( $p$-anisidine value) were measured.

The antioxidant activity of $\mathrm{N}$-acetyl-cysteine and glutathione at $50{ }^{\circ} \mathrm{C}$ is presented in Table 1 . The absorbance at $234 \mathrm{~nm}$ and $p$-anisidine value are presented, while the absorbance at $270 \mathrm{~nm}$ was not changed. Both thiols inhibited the increase of the absorbance at $234 \mathrm{~nm}$ and $p$-anisidine value during oil storage for up to 14 days. $N$-acetyl-cysteine ap-

Table 1. Inhibition of the Oxidation of Corn Oil Stripped of Tocopherols - A234 $\mathbf{n m}$ and $p$-Anisidine Value - by $N$-Acetyl-Cysteine and Glutathione During Storage at $50{ }^{\circ} \mathrm{C}$

\begin{tabular}{|c|c|c|c|c|c|c|c|}
\hline Sample & 0 days & 2 days & 4 days & 7 days & 10 days & 12 days & 14 days \\
\hline Control & \pm 0.020 & \pm 0.021 & \pm 0.019 & \pm 0.028 & \pm 0.038 & \pm 0.023 & \pm 0.032 \\
\hline BHA, $200 \mathrm{mg} / \mathrm{L}$ & $0.298^{\mathrm{a}}$ & $0.326^{\mathrm{b}}$ & $0.355^{\mathrm{c}}$ & $0.489^{\mathrm{d}}$ & $0.638^{\mathrm{d}}$ & $0.839^{d}$ & $0.948^{\mathrm{d}}$ \\
\hline \multirow[t]{2}{*}{$\mathrm{NAC}, 20 \mathrm{mg} / \mathrm{L}$} & $0.295^{\mathrm{a}}$ & $0.307^{\mathrm{b}}$ & $0.350^{\mathrm{c}}$ & $0.532^{\mathrm{c}}$ & $0.773^{c}$ & $0.999^{\mathrm{c}}$ & $1.194^{\mathrm{c}}$ \\
\hline & \pm 0.011 & \pm 0.015 & \pm 0.016 & \pm 0.040 & \pm 0.056 & \pm 0.030 & \pm 0.041 \\
\hline \multirow[t]{2}{*}{$\mathrm{GSH}, 20 \mathrm{mg} / \mathrm{L}$} & $0.298^{\mathrm{a}}$ & $0.339^{\mathrm{b}}$ & $0.437^{\mathrm{b}}$ & $0.695^{\mathrm{b}}$ & $1.134^{\mathrm{b}}$ & $1.777^{\mathrm{b}}$ & $2.251^{\mathrm{b}}$ \\
\hline & \pm 0.013 & \pm 0.041 & \pm 0.033 & \pm 0.021 & \pm 0.044 & \pm 0.008 & \pm 0.049 \\
\hline \multirow[t]{2}{*}{ BHA, $200 \mathrm{mg} / \mathrm{L}$} & $11.0^{\mathrm{a}}$ & $11.2^{\mathrm{b}}$ & $11.5^{\mathrm{b}}$ & $11.7^{\mathrm{b}}$ & $12.0^{\mathrm{c}}$ & $12.6^{\mathrm{d}}$ & $13.7^{\mathrm{d}}$ \\
\hline & \pm 0.0 & \pm 0.2 & \pm 0.1 & \pm 0.2 & \pm 0.2 & \pm 0.2 & \pm 0.8 \\
\hline \multirow[t]{2}{*}{$\mathrm{NAC}, 20 \mathrm{mg} / \mathrm{L}$} & $11.0^{\mathrm{a}}$ & $11.2^{\mathrm{b}}$ & $11.5^{\mathrm{b}}$ & $12.0^{\mathrm{b}}$ & $13.6^{\mathrm{b}}$ & $15.7^{\mathrm{c}}$ & $19.7^{\mathrm{c}}$ \\
\hline & \pm 0.0 & \pm 0.2 & \pm 0.2 & \pm 0.5 & \pm 0.6 & \pm 1.0 & \pm 2.4 \\
\hline \multirow[t]{2}{*}{$\mathrm{GSH}, 20 \mathrm{mg} / \mathrm{L}$} & $11.0^{\mathrm{a}}$ & $11.3^{\mathrm{b}}$ & $11.8^{\mathrm{a}, \mathrm{b}}$ & $12.9^{\mathrm{a}, \mathrm{b}}$ & $15.5^{\mathrm{a}, \mathrm{b}}$ & $19.6^{\mathrm{b}}$ & $28.3^{\mathrm{b}}$ \\
\hline & \pm 0.0 & \pm 0.2 & \pm 0.1 & \pm 0.6 & \pm 1.3 & \pm 1.5 & \pm 1.8 \\
\hline
\end{tabular}

Means are given with their standard deviation.

$\mathrm{a}, \mathrm{b}, \mathrm{c}, \mathrm{d}$ : Means of each index in every column without common superscript differ significantly at $p<0.05$. BHA=Butylated hydroxyanisole; NAC $=N$-acetyl-cysteine; GSH=Glutathione. 
peared to be more effective that glutathione. At $\mathrm{t}=12$ or 14 days, samples containing $20 \mathrm{mg} / \mathrm{L} N$-acetyl-cysteine exhibited absorbances at $234 \mathrm{~nm}$ less than $50 \%$ of those of the control samples. However, both thiols, each at $20 \mathrm{mg} / \mathrm{L}$, were less effective than BHA at $200 \mathrm{mg} / \mathrm{L}$. The ability of $N$ acetyl-serine and oxidized glutathione, each at $20 \mathrm{mg} / \mathrm{L}$, to inhibit oil oxidation at $50{ }^{\circ} \mathrm{C}$ was also evaluated at 0,7 and 14 days. However, both of them were inactive, since they did not affect A234 nm and $p$-anisidine values of samples (data not shown).

The antioxidant activity of $\mathrm{N}$-acetyl-cysteine and glutathione at $120{ }^{\circ} \mathrm{C}$ is presented in Table 2 . The absorbances at $234 \mathrm{~nm}$ and $270 \mathrm{~nm}$, and $p$-anisidine value are presented. Both thiols inhibited the increase of all three oxidation indexes during oil storage for up to 12 hours. $\mathrm{N}$-acetyl-cysteine appeared to be more effective than glutathione. However, both thiols, each at $30 \mathrm{mg} / \mathrm{L}$, were less effective than BHA at $200 \mathrm{mg} / \mathrm{L}$. The ability of $\mathrm{N}$-acetyl-serine and oxidized glutathione, each at $30 \mathrm{mg} / \mathrm{L}$, to inhibit oil oxidation at $120{ }^{\circ} \mathrm{C}$ was also evaluated at 0,3 and 6 hours. Both of them exhibited some antioxidant activity, since all three oxidation indexes were statistically lower than those of control. However, the decrease of three indexes in comparison to those of control was usually less than $10 \%$ with a maximum of $20 \%$. Their antioxidant abilities were much lower than those of $\mathrm{N}$ acetyl-cysteine and glutathione (data not shown).

The antioxidant activity of $N$-acetyl-cysteine and glutathione at $180{ }^{\circ} \mathrm{C}$ is presented in Table 3. The absorbances at $234 \mathrm{~nm}$ and $270 \mathrm{~nm}$ are presented. Both thiols inhibited the increase of these two oxidation indexes during oil storage for up to 120 minutes. $\mathrm{N}$-acetyl-cysteine appeared to be more effective than glutathione, while their action was dose

Table 2. Inhibition of The Oxidation of Corn Oil Stripped of Tocopherols - A234 nm, A270 $\mathrm{nm}$ and $p$-Anisidine Value - by $N$ Acetyl-Cysteine and Glutathione During Storage at $120{ }^{\circ} \mathrm{C}$

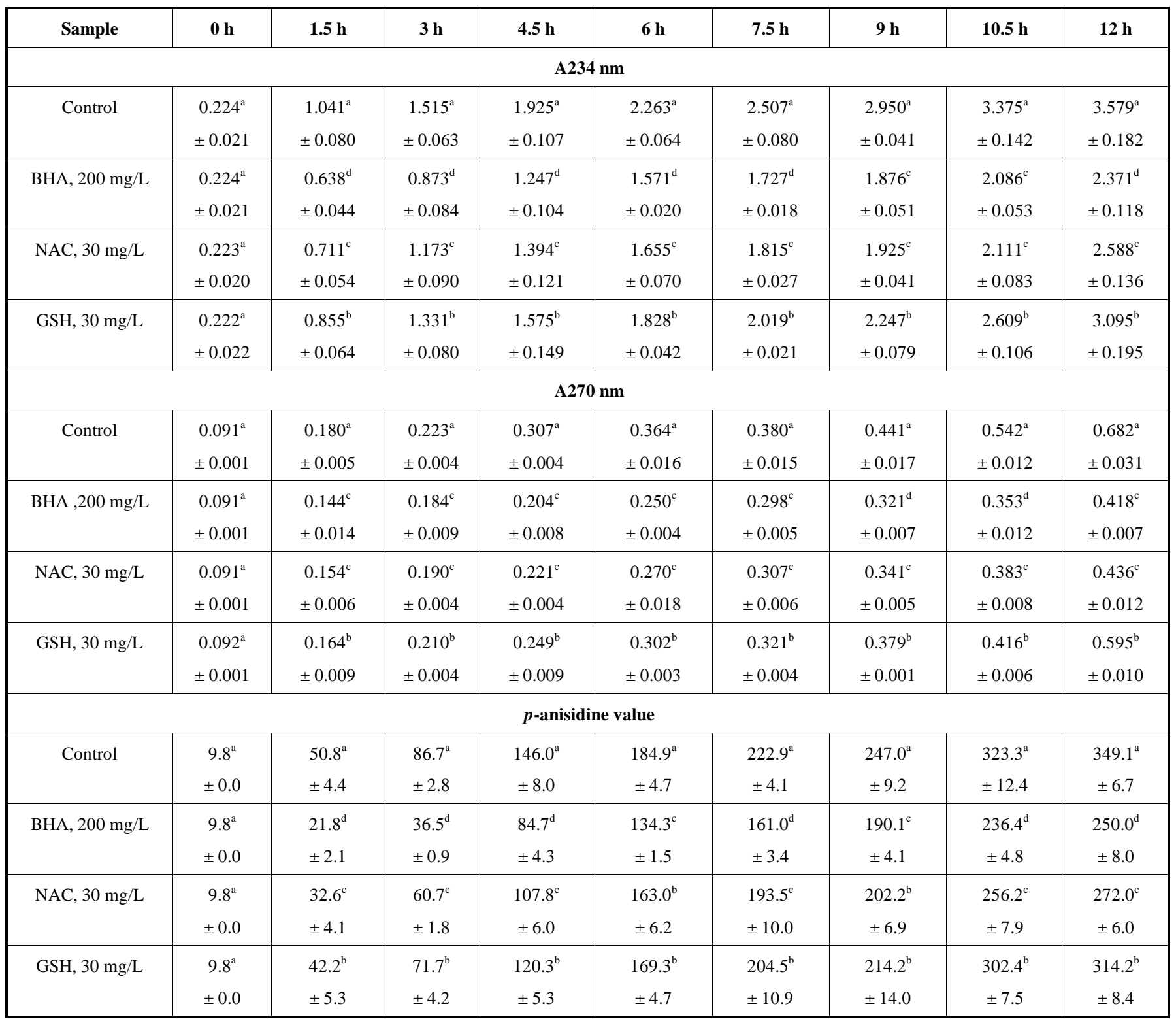

Means are given with their standard deviation.

$\mathrm{a}, \mathrm{b}, \mathrm{c}, \mathrm{d}$ : Means of each index in every column without common superscript differ significantly at $p<0.05$. BHA=Butylated hydroxyanisole; NAC $=N$-acetyl-cysteine; $\mathrm{GSH}=$ Glutathione. 
Table 3. Inhibition of the Oxidation of Corn Oil Stripped of Tocopherols - A234 nm and A270 nm - by $N$-Acetyl-Cysteine During Storage at $180^{\circ} \mathrm{C}$

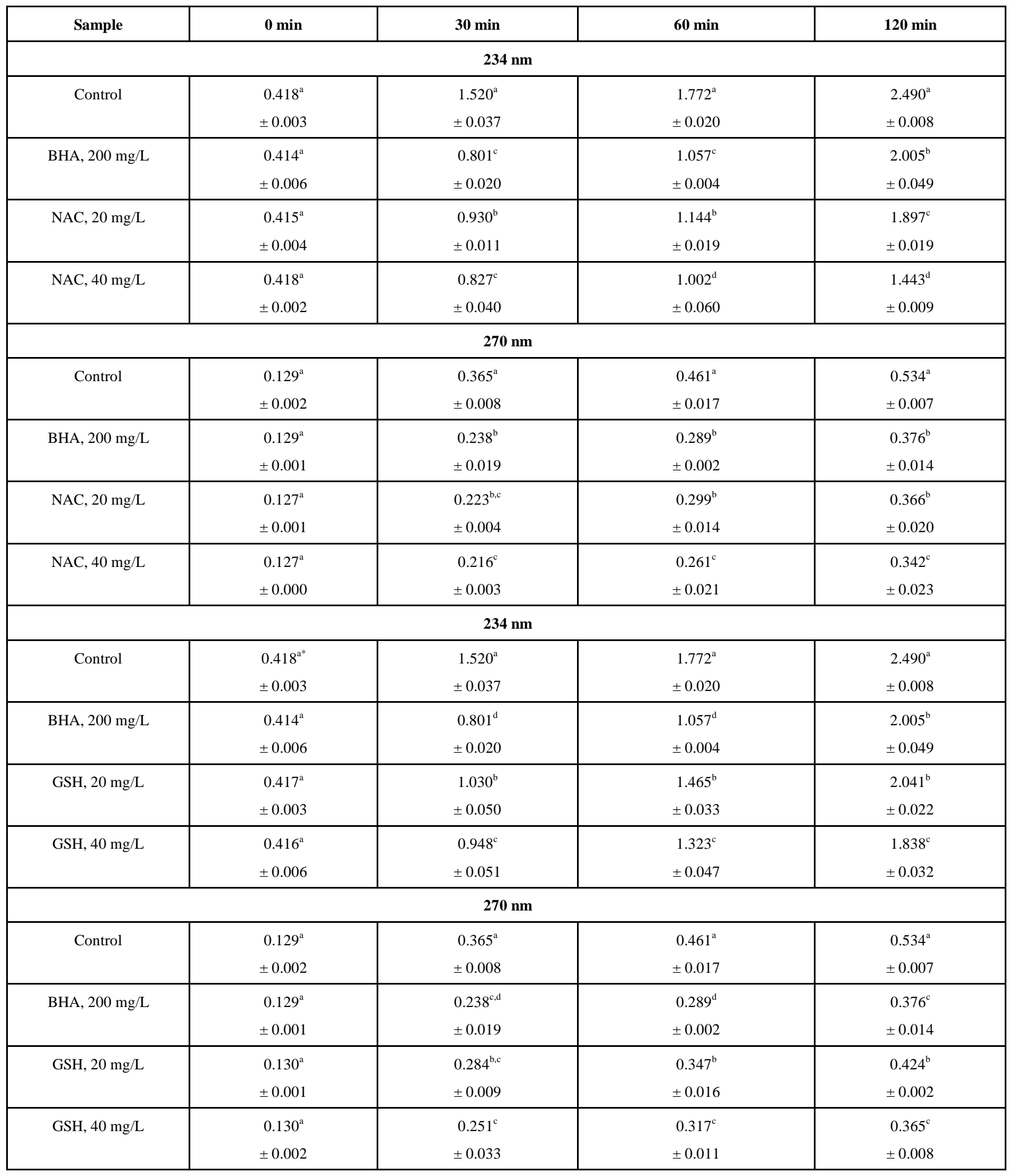

Means are given with their standard deviation.

a, b, c, d: Means of each index in every tetrad and column without common superscript differ significantly at $p<0.05$.

BHA=Butylated hydroxyanisole; $\mathrm{NAC}=N$-acetyl-cysteine; $\mathrm{GSH}=$ Glutathione. 
Table 4. Inhibition of the Oxidation of Refined Olive Oil - Peroxide Value- by $N$-Acetyl-Cysteine and Glutathione During Storage at $20{ }^{\circ} \mathrm{C}$

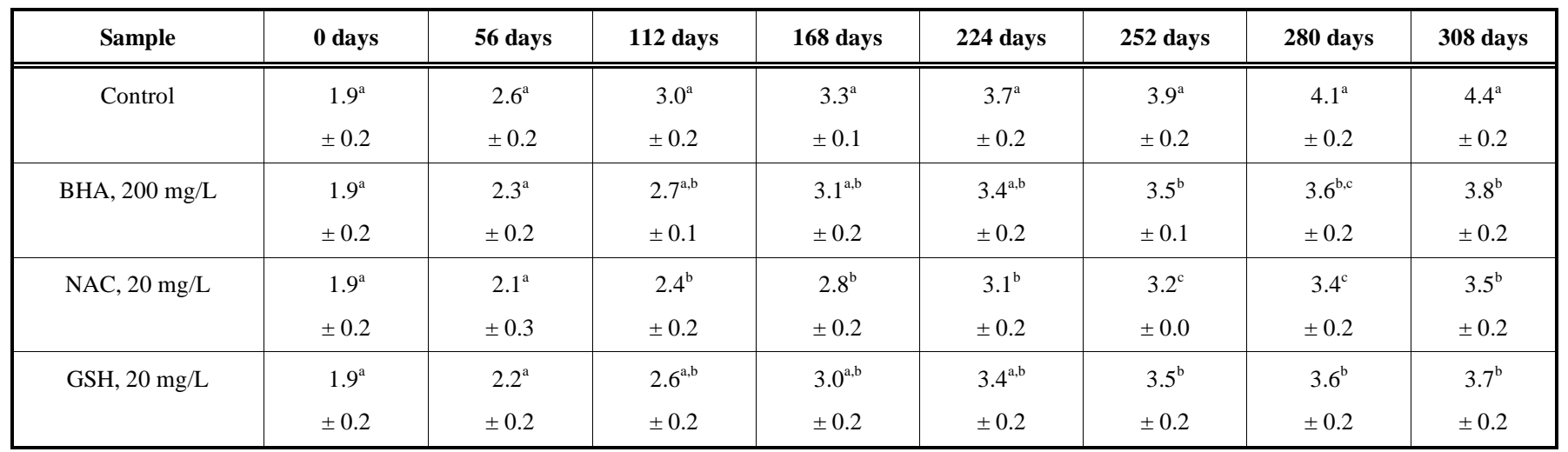

Means are given with their standard deviation.

$\mathrm{a}, \mathrm{b}, \mathrm{c}$ : Means in every column without common superscript differ significantly at $p<0.05$. BHA=Butylated hydroxyanisole; $\mathrm{NAC}=N$-acetyl-cysteine; $\mathrm{GSH}=\mathrm{Glutathione}$.

dependent. $\mathrm{N}$-acetyl-cysteine at $20 \mathrm{mg} / \mathrm{L}$ and glutathione at $40 \mathrm{mg} / \mathrm{L}$ exhibited antioxidant activities comparable to that of BHA at $200 \mathrm{mg} / \mathrm{L}$, while N-acetyl-cysteine at $40 \mathrm{mg} / \mathrm{L}$ higher than the synthetic antioxidant. The ability of $N$-acetylserine and oxidized glutathione, each at $40 \mathrm{mg} / \mathrm{L}$, to inhibit oil oxidation at $180{ }^{\circ} \mathrm{C}$ was also evaluated at 0,30 and 60 minutes. However, both of them were inactive, since they did not affect A234 nm and A270 nm of samples (data not shown).

$\mathrm{N}$-acetyl-cysteine and glutathione was also examined as inhibitors of the oxidation of refined olive oil at $20{ }^{\circ} \mathrm{C}$. Primary oxidation products were followed by determining conjugated dienes (peroxide values). The antioxidant activity of $\mathrm{N}$-acetyl-cysteine and glutathione is presented in Table 4. Both thiols, at $20 \mathrm{mg} / \mathrm{L}$, inhibited the increase of peroxide values during olive oil storage (period 252-308 days). They exhibited antioxidant activities comparable to that of BHA at $200 \mathrm{mg} / \mathrm{L}$. $\mathrm{N}$-acetyl-cysteine appeared to be more effective than glutathione.

Present results show that $\mathrm{N}$-acetyl-cysteine and glutathione are inhibitors of the oxidation of corn oil stripped of tocopherols and refined olive oil and that they are effective at $50{ }^{\circ} \mathrm{C}, 120{ }^{\circ} \mathrm{C}$ and $180{ }^{\circ} \mathrm{C}$, indicating the spectrum of their abilities. In oils used, $N$-acetyl-cysteine and glutathione exhibited antioxidant activities lower or similar to those of BHA. However, BHA was used typically at $200 \mathrm{mg} / \mathrm{L}$, while thiols at much lower concentrations since it has been taken into account their natural presence in foods. Glutathione is present in many foods at various levels, while some fruits and vegetables contain small amounts of $N$-acetyl-cysteine $[2,3]$. Results also show that compounds similar to $N$-acetylcysteine and glutathione but not containing - SH group, $\mathrm{N}$ acetyl-serine and oxidized glutathione, exhibited very low or no antioxidant activities. This indicates that the - $\mathrm{SH}$ group is essential for antioxidant activities of the two thiols in oils.
Previously, it was reported that $\mathrm{N}$-acetyl-cysteine and glutathione inhibit the oxidation of corn oil [8, 10]. Present results show the ability of thiols to inhibit the oxidation of corn oil stripped of tocopherols and refined olive oil indicating that they can inhibit the oxidation of any oil.

\section{ACKNOWLEDGEMENT}

For this work, the GC-MS facilities of the Food Quality Certification Unit of the University of Ioannina have been used.

\section{REFERENCES}

[1] Friedman M. Improvement in the safety of foods by SH-containing amino acids and peptides. A review. J Agric Food Chem 1994; 42 : 3-20.

[2] Jones DP, Coates RJ, Flagg EW, et al. Glutathione in foods listed in the national cancer institute's health habits and history food frequency questionnaire. Nutr Cancer 1992; 17: 57-75.

[3] Demirkol O, Adams C, Ercal N. Biologically important thiols in various vegetables and fruits. J Agric Food Chem 2004; 52: 81514.

[4] Anton R, Barlow S, Boskou D, et al. $N$-acetyl-L-cysteine for use in foods for particular nutritional usesand in foods for special medicinal purposes. Eur Food Saf Auth J 2003; 21: 1-8.

[5] SJadhan SJ, Nimbalkar SS, Kulkarni AD, Madhavi DL. Lipid oxidation in biological and food systems. In: Madhavi DL, Deshpande SS, Salunkhe DK, Eds. Food antioxidants. New York, NY : Marcel Dekker 1994.

[6] Ahmad MM, Al-Hakim S, Adel A, Shehata AAY. The antioxidant activity of amino acids in two vegetable oils. J Am Oil Chem Soc 1982; 60: 837-40.

[7] Papadopoulou D, Roussis IG. Inhibition of corn oil oxidation by thiols. Ital J Food Sci 2000; 2: 239-42.

[8] Yin M-C, Cheng W-S. Antioxidant and antimicrobial effects of four garlic-derived organosulfur compounds in ground beef. Meat Sci 2003; 63: 23-8.

[9] Papadopoulou D, Roussis IG. Inhibition of corn oil oxidation by $\mathrm{N}$ acetyl-cysteine and glutathione. Food Chem 2008; 109: 624-9.

[10] Helrich K, Ed. Official methods of analysis of the association of official analytical chemists. $15^{\text {th }}$ ed. Arlington, VA: AOAC 2002.

(C) Roussis et al.; Licensee Bentham Open.

This is an open access article licensed under the terms of the Creative Commons Attribution Non-Commercial License (http://creativecommons.org/licenses/by-nc/3.0/) which permits unrestricted, non-commercial use, distribution and reproduction in any medium, provided the work is properly cited. 